\title{
Vanadium(V) Complex-Catalyzed One-Pot Synthesis of Phenanthridines via a Pictet-Spengler-Dehydrogenative Aromatization Sequence
}

\author{
Makoto Sako ${ }^{1}$, Romain Losa ${ }^{1,2}$, Tomohiro Takiishi ${ }^{1}$, Giang Vo-Thanh ${ }^{2}$, Shinobu Takizawa ${ }^{1, *}$ \\ and Hiroaki Sasai ${ }^{1, *}$ \\ 1 The Institute of Scientific and Industrial Research, Osaka University, Mihogaoka, Ibaraki-shi, \\ Osaka 567-0047, Japan; sako43@sanken.osaka-u.ac.jp (M.S.); romain.losa@universite-paris-saclay.fr (R.L.); \\ takiishi43@sanken.osaka-u.ac.jp (T.T.) \\ 2 Institut de Chimie Moléculaire et des Matériaux d'Orsay, ICMMO, UMR 8182, Laboratoire de Catalyse \\ Moléculaire, Université Paris-Saclay, CEDEX, 91405 Orsay, France; giang.vo-thanh@universite-paris-saclay.fr \\ * Correspondence: taki@sanken.osaka-u.ac.jp (S.T.); sasai@sanken.osaka-u.ac.jp (H.S.); \\ Tel.: +81-6-6879-8466 (S.T.); +81-6-6879-8465 (H.S.)
}

Received: 2 July 2020; Accepted: 26 July 2020; Published: 2 August 2020

\begin{abstract}
Phenanthridine and its derivatives are important structural motifs that exist in natural products, biologically active compounds, and functional materials. Here, we report a mild, one-pot synthesis of 6-arylphenanthridine derivatives by a sequential cascade Pictet-Spengler-dehydrogenative aromatization reaction mediated by oxovanadium $(\mathrm{V})$ complexes under aerobic conditions. The reaction of 2-(3,5-dimethoxyphenyl)aniline with a range of commercially available aryl aldehydes provided the desired phenanthridine derivatives in up to $96 \%$ yield. The ability of vanadium(V) complexes to function as efficient redox and Lewis acid catalysts enables the sequential reaction to occur under mild conditions.
\end{abstract}

Keywords: phenanthridines; catalysis; Pictet-Spengler; Lewis acid; heteroarenes; dehydrogenative aromatization; vanadium $(\mathrm{V})$; domino reaction

\section{Introduction}

Phenanthridine and its structurally related compounds play essential roles in a variety of chemical fields due to their existence in a broad range of natural products, bioactive compounds, and functional materials (Figure 1) [1-5]. Phenanthridine was first synthesized from the reaction between benzaldehyde and aniline in 1889 [6], and a number of preparative methods have been reported to date [1,7-9]. However, since most protocols necessitate harsh reaction conditions and/or multi-step reaction sequences from commercially available starting materials [10,11], concise and mild preparation procedures for this important class of compounds are still in high demand [12-15].

Organometallic vanadium $(\mathrm{V})$ complexes have been employed in the development of a wide range of organic reactions [16-23]. Their high valency and ability to exist in multiple oxidation states enable vanadium complexes to act as Lewis acid and/or redox catalysts. We theorized that these functionalities can be used to perform domino reaction sequences in a single operation. Furthermore, there are a few reports on the cooperative effect of vanadium $(\mathrm{V})$ complexes in synthesis [24-28]. 
<smiles></smiles>

protein kinase $\mathrm{C}$ inhibitor and antibacterial activity<smiles></smiles>

ethidium $^{3}$

used in fluorescence assays with nucleic acids<smiles>NP(N)(N)=Nc1ccccc1-c1ccccc1</smiles>

phenanthriplatin 4 anticancer<smiles>O=P(=O)c1ccc2c(-c3ccccc3)nc(-c3ccccc3)c(-c3ccccc3)c2c1</smiles>

chiral ligand

Figure 1. Examples of phenanthridine derivatives.

Recently, we developed chiral oxovanadium complexes [29] that act as redox and/or Lewis acid catalysts for the enantioselective oxidative coupling of arenols [30-33], Friedel-Crafts-type reactions [34], and a sequential cascade reaction that affords oxahelicenes [28]. As part of our ongoing research, we envisioned a one-pot synthesis of phenanthridine derivatives $\mathbf{5}$ using vanadium $(\mathrm{V})$ complexes $\mathbf{6}$ as Lewis acid/oxidation catalysts (Scheme 1). Thus, Lewis acidic vanadium(V) complex 6 would promote a Pictet-Spengler reaction of imine intermediate 3 formed by the condensation of aniline 1 and benzaldehyde 2 to afford tetrahydroisoquinoline 4 . A subsequent dehydrogenative aromatization of $\mathbf{4}$, assisted by the same vanadium(V) complex, now operating as a one-electron oxidant, would yield the desired phenanthridine product $5[28,35]$.

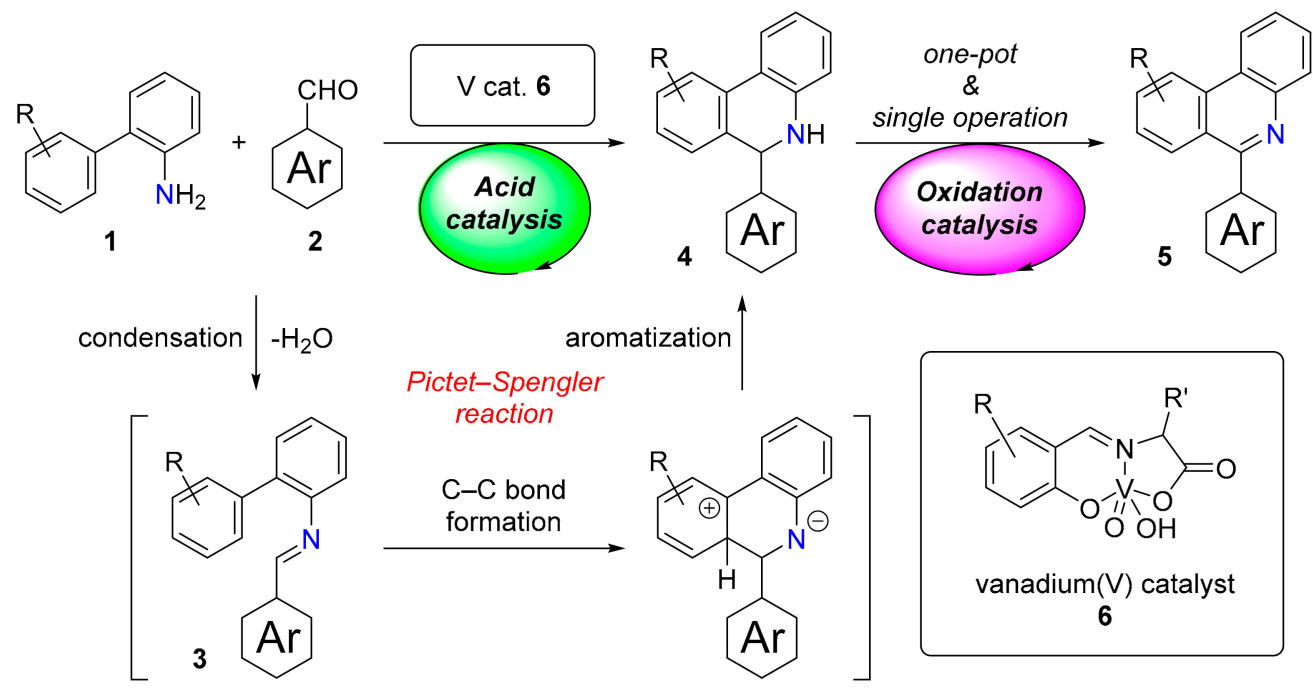

Scheme 1. This work: synthesis of phenanthridines derivatives by a vanadium(V)-catalyzed PictetSpengler-dehydrogenative aromatization reaction sequence.

\section{Results and Discussion}

Our initial investigations focused on the reaction between 2-(3,5-dimethoxyphenyl)aniline (1a) and benzaldehyde (2a) (1.2 equivalents) using vanadium(V) catalyst rac-6a $(10 \mathrm{~mol} \%)$ in various solvents at $50{ }^{\circ} \mathrm{C}$ (Table 1). The reaction in tetrahydrofuran (THF) afforded the desired product $5 \mathbf{a}$ in $31 \%$ yield (Entry 1), however, the reaction cascade performed markedly better in dichloromethane, toluene, and acetonitrile (Entries 2-4). Of the solvents tested, acetonitrile (MeCN) gave the best outcome, affording $\mathbf{5 a}$ in $95 \%$ yield (Entry 4$)$. Next, we turned our attention to the vanadium(V) catalyst complex. Catalysts (S)-6b and (S)-6c bearing an iso-propyl and tert-butyl group, respectively, showed comparable catalytic activities to rac-6a (Figure 2), which contains a benzyl group on the amino acid moiety (Entries 5 and 6). The bulkier di-tert-butyl-substituted catalyst (S)-6d and naphthalene-based catalyst (S)-6e resulted in lower yields of $\mathbf{5 a}, 68 \%$ and $85 \%$, respectively (Entries 7 and 8 ). The optimum temperature 
for the reaction was $50{ }^{\circ} \mathrm{C}$. A significantly diminished yield of product $5 \mathbf{a}$ was observed at $40{ }^{\circ} \mathrm{C}$, which may be attributed to suppression of the Pictet-Spengler-dehydrogenative aromatization cascade (Entry 9), whereas the marginally lower yields recorded at $60^{\circ} \mathrm{C}$ and $70{ }^{\circ} \mathrm{C}$ (Entries 10 and 11) may be due to partial decomposition of the vanadium complex. Only a trace amount of phenanthridine $5 \mathbf{a}$ was obtained in the absence of the catalyst (Entry 12). The commercially available vanadium(V) and vanadium(IV) catalysts, $\mathrm{V}_{2} \mathrm{O}_{5}$ and $\mathrm{VOSO}_{4}$ respectively, displayed poor activity; less than $15 \%$ yield of $5 \mathrm{a}$ observed after $72 \mathrm{~h}$ at $50{ }^{\circ} \mathrm{C}$ in both cases (Entry 13). Finally, we decided on the optimal reaction conditions of $10 \mathrm{~mol} \%$ of catalyst $(S)-6 \mathbf{b}$ in $\mathrm{MeCN}(0.2 \mathrm{M})$ at $50{ }^{\circ} \mathrm{C}$, shown in Entry 4, to continue with our studies; due to the lower cost of $(S)$-valine than that of the racemic amino acids and other optically pure amino acids, chiral vanadium complex (S)-6b with the high activity was selected as an appropriate catalyst for this reaction.

Table 1. Screening of reaction conditions.

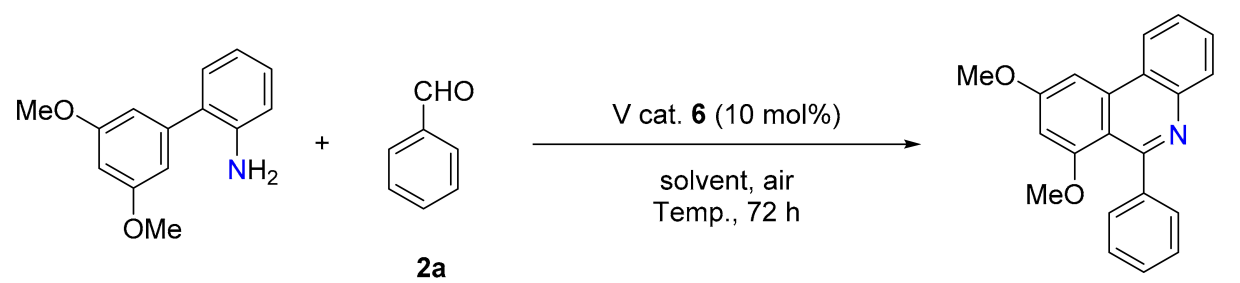

$1 \mathrm{a}$

(1.2 equiv)

$5 a$

\begin{tabular}{ccccc}
\hline Entry & V cat (10 $\mathbf{~ m o l} \%)$ & Solvent & Temp. $\left({ }^{\circ} \mathbf{C}\right)$ & Yield of 5a (\%) $\mathbf{~}^{\mathbf{1}}$ \\
\hline 1 & rac-6a & $\mathrm{THF}$ & 50 & $31^{2}$ \\
2 & rac-6a & $\mathrm{CH}_{2} \mathrm{Cl}_{2}$ & reflux & 86 \\
3 & rac-6a & Toluene & 50 & 89 \\
4 & rac-6a & $\mathrm{MeCN}$ & 50 & 95 \\
5 & $(S)-\mathbf{6 b}$ & $\mathrm{MeCN}$ & 50 & 95 \\
6 & $(S)-\mathbf{6 c}$ & $\mathrm{MeCN}$ & 50 & 91 \\
7 & $(S)-\mathbf{6 d}$ & $\mathrm{MeCN}$ & 50 & $68^{2}$ \\
8 & $(S)-\mathbf{6 e}$ & $\mathrm{MeCN}$ & 50 & 85 \\
9 & $(S)-\mathbf{6 b}$ & $\mathrm{MeCN}$ & 40 & $35^{2}$ \\
10 & $(S)-\mathbf{6 b}$ & $\mathrm{MeCN}$ & 60 & 87 \\
11 & $(S)-\mathbf{6 b}$ & $\mathrm{MeCN}$ & 70 & 75 \\
12 & - & $\mathrm{MeCN}$ & 50 & Trace \\
13 & $\mathrm{~V}_{2} \mathrm{O}_{5}$ or $\mathrm{VOSO}$ & $\mathrm{MeCN}$ & 50 & $<15^{2}$ \\
\hline
\end{tabular}

${ }^{1}$ Determined by ${ }^{1} \mathrm{H}$ NMR using 1,3,5-trimethoxybenzene as an internal standard. ${ }^{2}$ Imine $3 \mathbf{a}$ and tetrahydroisoquinoline 4a were observed by ${ }^{1} \mathrm{H}$ NMR.<smiles>Cc1cc(Br)cc(Br)c1C</smiles>

$(S)-6 d$

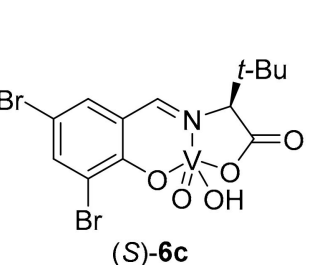

(S)-6c<smiles>COc1cc(OC)cc(-c2ccccc2/N=C/P)c1</smiles>

Figure 2. Structures of vanadium(V) complexes and observed intermediates. 
Under the optimal reaction conditions, we conducted the one-pot reaction sequence on a range of aryl aldehydes (2a-y Table 2). Benzaldehydes $\mathbf{2 a - q}$, containing electron-donating and electron-withdrawing groups in the para-, meta-, or ortho-positions, underwent smooth transformations to give the corresponding 6-arylphenanthridines $5 \mathbf{a}-\mathbf{q}$ in $72-96 \%$ yields. Notably, the reaction exhibited high functional group tolerance as evident by the presence of phenolic $(\mathbf{5 c})$, cyano $(\mathbf{5 e})$, halide $(\mathbf{5 f}-\mathbf{h}$, $\mathbf{5 k}-\mathbf{o}$ ), and nitro (5j and $\mathbf{5 q}$ ) substituents. The reaction of di- and penta-substituted benzaldehydes $\mathbf{2 r}$ and $\mathbf{2 s}$ afforded the products $\mathbf{5 t}$ and $\mathbf{5 u}$ in $78 \%$ and $85 \%$ yields, respectively. When 2-naphthaldehydes $(5 \mathbf{t}$ and $\mathbf{5 u})$ and 1-naphthaledehydes (5e-x) were employed, the desired products $5 \mathbf{t}-\mathbf{x}$ were also obtained in moderate to good yields. We were also pleased to observe that bipyridine derivative $5 y$ was synthesized in $83 \%$ yield using 2 -formylpyridine.

Table 2. Substrate scope.
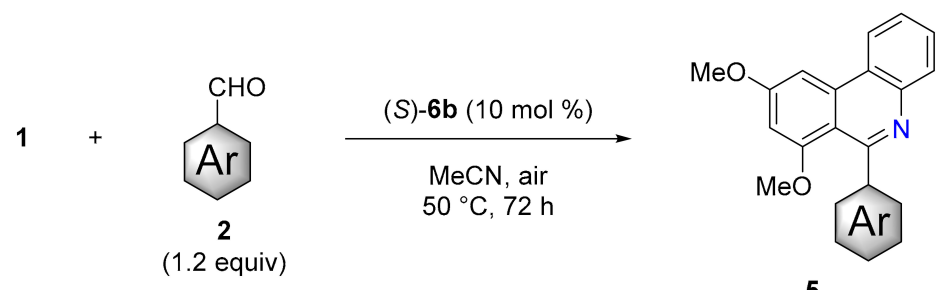

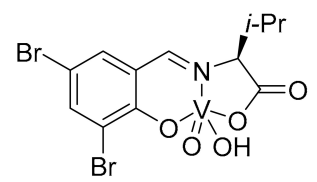

(S)-6b

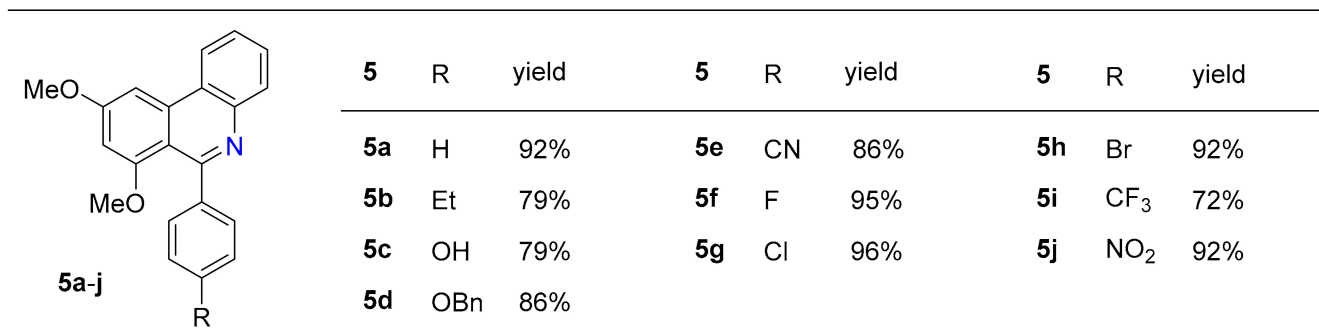<smiles>[R]c1cccc(-c2nc3ccccc3c3cc(OC)cc(OC)c23)c1</smiles><smiles>COc1cc(OC)c2c(-c3cc(Br)ccc3OC)nc3ccccc3c2c1</smiles>

$5 r, 78 \%$<smiles>COc1cc(OC)c2c(-c3cccc4ccccc34)nc3ccccc3c2c1</smiles>

5v, $89 \%$<smiles>COc1cc(OC)c2c(-c3c(F)c(F)c(F)c(F)c3F)nc3ccccc3c2c1</smiles>

5s, $85 \%$

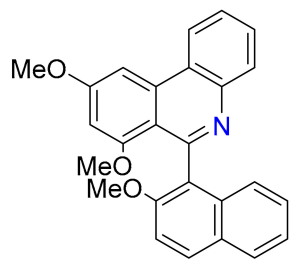

$5 w, 78 \%$<smiles>COc1cc(OC)c2c(-c3ccc4ccccc4c3)nc3ccccc3c2c1</smiles>

5t, $69 \%$<smiles>COc1cc(OC)c2c(-c3c(OC)ccc4ccccc34)nc3ccccc3c2c1</smiles>

5x, $95 \%$<smiles>COc1ccc2c(-c3nc4ccccc4c4cc(OC)cc(OC)c34)cccc2c1</smiles><smiles>COc1cc(OC)c2c(-c3ccccn3)nc3ccccc3c2c1</smiles>

5y, $83 \%$ 
A plausible catalytic cycle for the vanadium(V)-catalyzed cascade reaction of aniline 1a with benzaldehyde 2a is shown in Figure 3. In the first step, condensation of 1a with 2a occurs to give imine 3a. Subsequently, the vanadium $(\mathrm{V})$ complex $(S)-6 \mathbf{b}$ promotes the intramolecular cyclization of the imine via complex $\mathbf{A}$; this key carbon-carbon bond forming step completes construction of the phenanthridine core and affords the intermediate $\mathbf{B}$ [34]. Intermediate $\mathbf{C}$ is generated after re-aromatization of $\mathbf{B}$. At this stage in the cycle, the addition of water to $\mathbf{C}$ might yield tetrahydroisoquinoline $\mathbf{4 a}$, which was observed by proton nuclear magnetic resonance $\left({ }^{1} \mathrm{H}\right.$ NMR) analysis (vide supra), and $(S)-6 \mathbf{b}$. Dehydrogenative aromatization of $4 \mathbf{a}$ proceeds via intermediate $\mathbf{C}$ and a single-electron transfer from the electron-rich nitrogen center to vanadium $(V)$ forms the intermediate $\mathbf{D}$, which undergoes the dehydrogenative aromatization to give the desired product $5 \mathbf{a}$ [35]; when (2,2,6,6-tetramethylpiperidin-1-yl)oxidanyl (TEMPO) (1.0 equivalent) was added to the optimal conditions, no desired product $5 \mathbf{a}$ was obtained at all. Under degassed $\mathrm{N}_{2}$ instead of air, the sequential reaction proceeded to give $5 \mathbf{a}$, probably due to easily auto-oxidation of $4 \mathbf{a}$ during analysis. Finally, oxidation of vanadium(IV) by molecular oxygen regenerates the vanadium(V) complex (S)-6b.

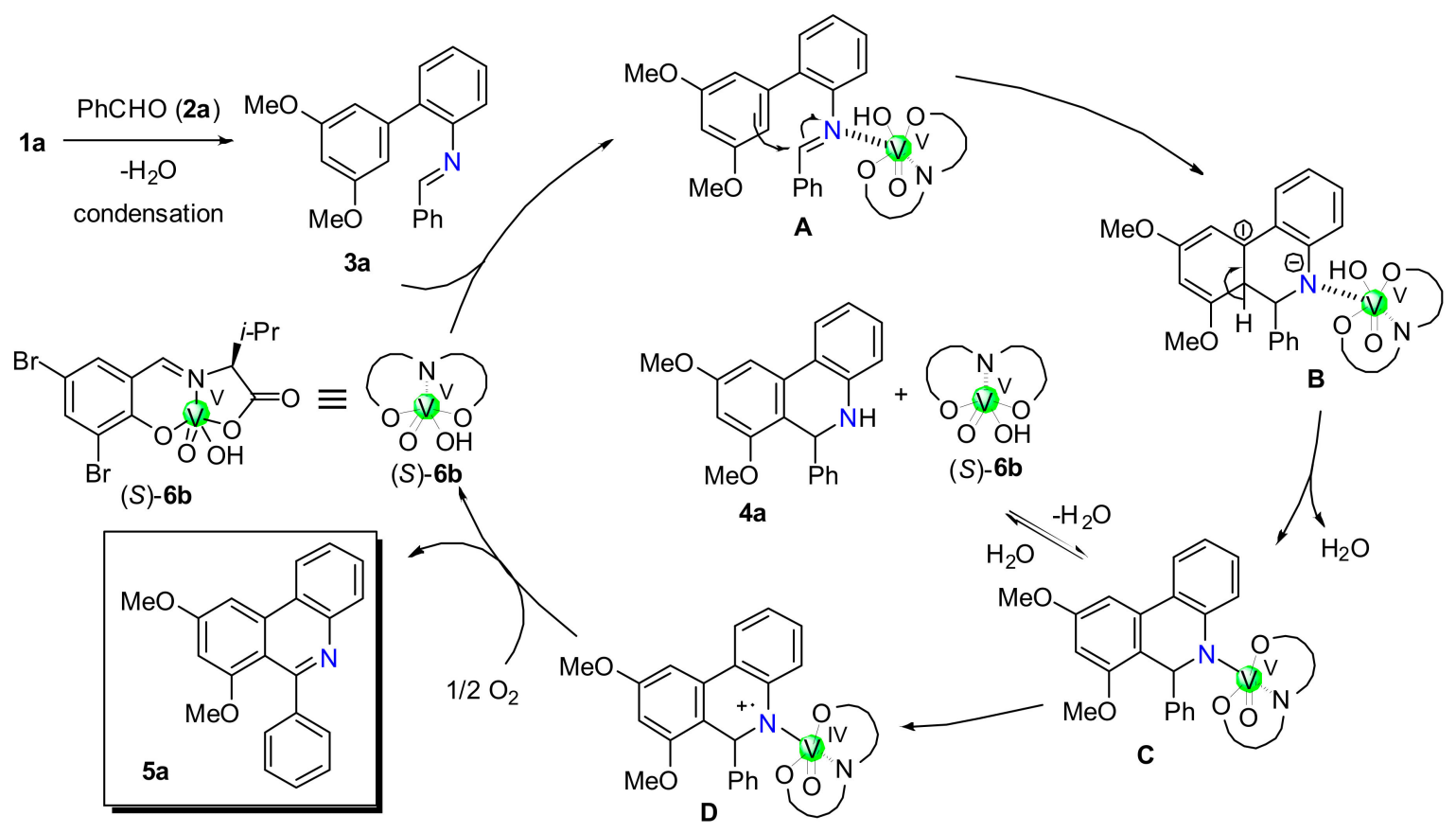

Figure 3. A plausible catalytic cycle for the vanadium(V)-catalyzed Pictet-Spengler-dehydrogenative aromatization cascade reaction of aniline $\mathbf{1} \mathbf{a}$ and benzaldehyde $\mathbf{2} \mathbf{a}$.

In order to realize an enantioselective vanadium(V)-catalyzed domino cascade reaction, we turned our attention to the construction of trimethoxyphenanthridine derivative $5 \mathbf{w}$ (Scheme 2), which contains an axis of chirality and potentially has a role as a chiral reagent such as 6-(2'-diphenylphosphino$1^{\prime}$-naphthyl)phenanthridine (PHENAP) ligand in Figure 1. In a preliminary study, treatment of aniline $1 \mathrm{a}$ and 2-methoxy-1-naphthaldehyde $(\mathbf{2 w})$ with binaphthol vanadium $(\mathrm{V}) \operatorname{complex}\left(R_{\mathrm{a}}, S\right)$-6f in chloroform $\left(\mathrm{CHCl}_{3}\right)$ at $20{ }^{\circ} \mathrm{C}$ successfully afforded $5 \mathrm{w}$ in moderate yield and $65 \%$ ee. X-ray crystallographic analysis of optically pure $5 \mathrm{w}$ (The Cambridge crystallographic data centre number: CCDC 2005061) was performed after the optical resolution of the mixture involving the major product $5 \mathbf{w}$ by using preparative chiral high-performance liquid chromatography (chiral HPLC) (CHIRALPAK IC, $n$-hexane $/ i-\mathrm{PrOH}=2 / 1, \mathrm{v}=10 \mathrm{~mL} \mathrm{~min}^{-1}, \lambda=231 \mathrm{~nm}$ ). The absolute configuration of $5 \mathrm{w}$ with catalyst $\left(R_{\mathrm{a}}, S\right)$-6f was determined to be $S$ based on the Flack parameter (0.02(6)). The tetrahydroisoquinoline intermediate $4 \mathbf{w}$ readily underwent auto-dehydrogenative aromatization, which implies that the enantioenrichment step may be the carbon-carbon bond-forming step of the Pictet-Spengler reaction, i.e., intermediate A to intermediate B (Figure 3); we clarified a possibility of kinetic resolution of 
rac-4b [36] using catalyst $\left(R_{\mathbf{a}}, S\right)-\mathbf{6} \mathbf{f}$ under the reaction conditions as shown in Scheme 2 because isolation of $4 \mathbf{w}$ was difficult due to its stability. After $3 \mathrm{~h}, 70 \%$ of $4 \mathbf{b}$ was converted to $5 \mathbf{b}$ and the optical purity of the recovered $4 \mathrm{~b}$ was $8 \%$ ee. Additional investigation of the enantioselective reaction mechanism from both experimental and theoretical perspectives is now in progress.

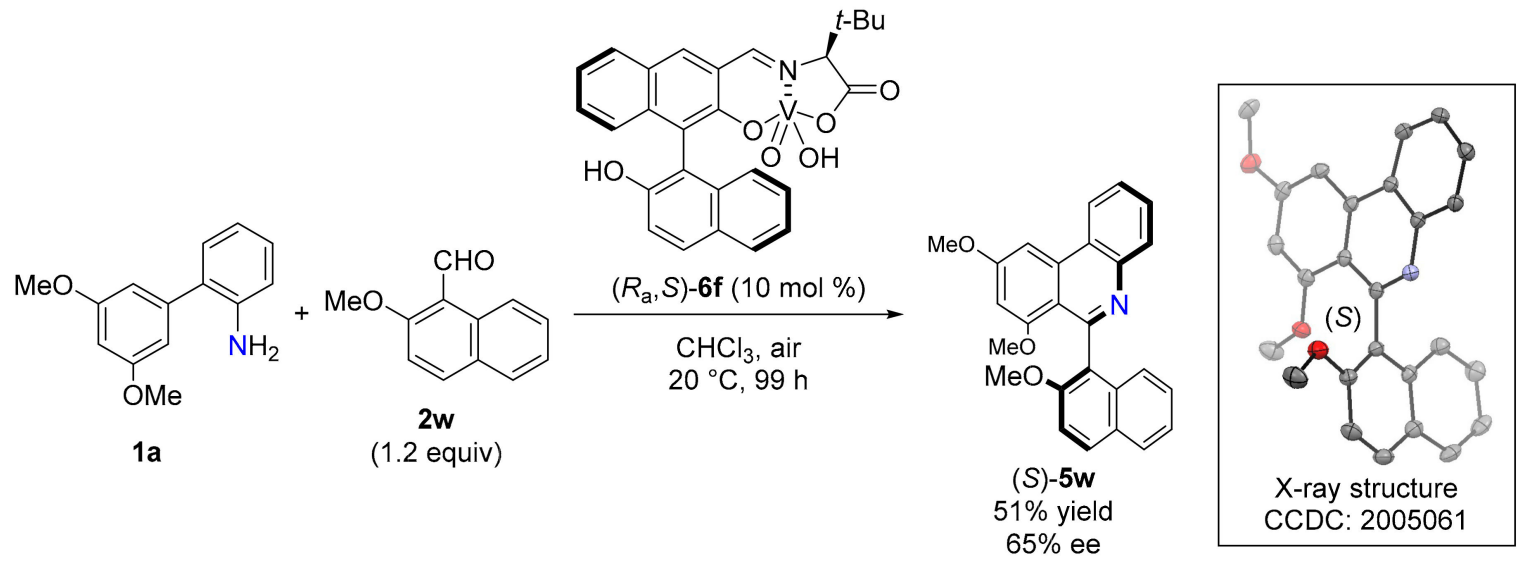

Scheme 2. Enantioselective domino reaction towards axially chiral phenanthridine derivative $\mathbf{5 w}$.

\section{Materials and Methods}

${ }^{1} \mathrm{H}-,{ }^{13} \mathrm{C}-$, and ${ }^{19} \mathrm{~F}-\mathrm{NMR}$ were recorded with JEOL JMN ECS400 FT NMR, JNM ECA600 FT NMR (JEOL, Tokyo, Japan) or Bruker AVANCE II (BRUKER, Billerica, MA, USA) $\left({ }^{1} \mathrm{H}-\mathrm{NMR}\right.$ 400, 600, or $700 \mathrm{MHz},{ }^{13} \mathrm{C}-\mathrm{NMR}$ 100, 150, or $175 \mathrm{MHz},{ }^{19} \mathrm{~F}-\mathrm{NMR} 376 \mathrm{MHz}$.) ${ }^{1} \mathrm{H}-\mathrm{NMR}$ spectra (see Supplementary Materials) are reported as follows: chemical shift in ppm relative to the chemical shift of tetramethylsilane (TMS) at $0 \mathrm{ppm}$, integration, multiplicities $(\mathrm{s}=$ singlet, $\mathrm{d}=$ doublet, $\mathrm{t}=$ triplet, $\mathrm{q}=$ quartet, $\mathrm{m}=$ multiplet), and coupling constants $(\mathrm{Hz}) \cdot{ }^{13} \mathrm{C}-\mathrm{NMR}$ spectra reported in ppm relative to the central line of triplet for $\mathrm{CDCl}_{3}$ at $77.0 \mathrm{ppm} . \mathrm{CF}_{3} \mathrm{CO}_{2} \mathrm{H}$ used as external standards for ${ }^{19} \mathrm{~F}-\mathrm{NMR}$. FT-MS spectra were obtained with LTQ Orbitrap XL (Thermo Fisher Scientific, Waltham, MA, USA). ESI-MS spectra were obtained with JMS-T100LC (JEOL, Tokyo, Japan). FT-IR spectra were recorded on a JASCO FT-IR system (FT/IR4100) (JASCO, Tokyo, Japan). Column chromatography on $\mathrm{SiO}_{2}$ was performed with Kanto Silica Gel $60(63-210 \mu \mathrm{m})$. Commercially available organic and inorganic compounds were used without further purification.

\subsection{Vanadium(V) Complex-Catalyzed Pictet-Spengler Reaction and Dehydrogenative Aromatization Sequence}

In a test tube, to a solution of a 2-(3,5-dimethoxyphenyl)aniline (1a) in acetonitrile $(0.2 \mathrm{M})$ a benzaldehyde derivate 2 (1.2 eq) and a mononuclear vanadium catalyst $(S)-6 \mathbf{b}(10 \mathrm{~mol} \%)$ were added. The reaction was stirred at $50{ }^{\circ} \mathrm{C}$ for $72 \mathrm{~h}$ under air atmosphere. After the reaction, the reaction mixture was concentrated in vacuo and purified by silica column chromatography using hexane/acetone as eluent to afford the phenanthridine derivatives 5 .

\subsection{Enanitoselective Reaction}

In a test tube, to a solution of $\mathbf{1 a}$ in chloroform $(0.1 \mathrm{M}), 2$-methoxy-1-naphthaldehyde $\mathbf{2} \mathbf{w}$ (1.2 equivalent), and a mononuclear vanadium catalyst $\left(R_{\mathrm{a}}, S\right)-6 \mathbf{f}(10 \mathrm{~mol} \%)$ were added. The reaction was stirred at $20^{\circ} \mathrm{C}$ under air atmosphere. After $99 \mathrm{~h}$, the reaction mixture was concentrated in vacuo and purified by preparative thin-layer chromatography using hexane/dichloromethane/ethyl acetate (5/5/1) as eluent to afford (S)-7,9-dimethoxy-6-(2-methoxynaphthalen-1-yl)phenanthridine 5w in 51\% yield with $65 \%$ ee. 


\section{Conclusions}

Vanadium $(\mathrm{V})$-catalyzed domino reactions for the efficient synthesis of phenanthridines have been achieved. Vanadium(V) complexes promote a Pictet-Spengler-dehydrogenative aromatization cascade due to their ability to mediate Lewis acid and oxidative catalysis under mild reaction conditions. The vanadium catalysis exhibited high functional group tolerance using various aryl aldehydes. Furthermore, a chiral vanadium $(\mathrm{V})$ complex was applied to the enantioselective synthesis of an axially chiral phenanthridine derivative. Further applications of the reaction to other aniline derivatives are ongoing in our laboratory.

Supplementary Materials: The following are available online at http://www.mdpi.com/2073-4344/10/8/860/s1. SI-1: Compound Data, SI-2: NMR Spectra, SI-3: HPLC Chromatograms, SI-4: X-ray Crystallographic Analysis of (S)-5w.

Author Contributions: Data curation, visualization, and writing (original draft preparation, review and editing), M.S.; data curation and investigation, R.L. and T.T.; supervision, G.V.-T.; conceptualization, supervision, and writing (review and editing), S.T.; supervision, writing (review and editing), H.S. All authors have read and agreed to the published version of the manuscript.

Funding: This research was funded by JSPS KAKENHI Grant Numbers 18K14220 in Early-Career Scientists, JP18KK0154 in Promotion of Joint International Research (Fostering Joint International Research(B), The Ministry of Education, Culture, Sports, Science, and Technology (MEXT), and the Japan Society for the Promotion of Science (JSPS), Daiichi Sankyo Foundation of Life Science, and Hoansha Foundation.

Acknowledgments: We acknowledge the technical staff of the Comprehensive Analysis Center of ISIR, and Artificial Intelligence Research Center of ISIR, Osaka University (Japan). We are grateful to the University Paris-Saclay for a mobility grant to R.L.

Conflicts of Interest: The authors declare no conflicts of interest.

\section{References}

1. Rafiee, F. Synthesis of phenanthridine and phenanthridinone derivatives based on Pd-catalyzed C-H activation. Appl. Organometal. Chem. 2017, 31, e3820. [CrossRef]

2. Herbert, J.M.; Augereau, J.M.; Gleye, J.; Maffrand, J.P. Chelerythrine is a Potent and Specific Inhibitor of Protein Kinase C. Biochem. Biophys. Res. Commun. 1990, 172, 993-999. [CrossRef]

3. Olemsted, J.; Kearns, D.R. Mechanism of Ethidium Bromide Fluorescence Enhancement on Binding to Nucleic Acids. Biochemistry 1977, 16, 3647-3654. [CrossRef] [PubMed]

4. Park, G.Y.; Wilson, J.J.; Song, Y.; Lippard, S.J. Phenanthriplatin, a Monofunctional DNA-binding Platinum Anticancer Drug Candidate with Unusual Potency and Cellular Activity Profile. Proc. Natl. Acad. Sci. USA 2012, 109, 11987-11992. [CrossRef]

5. Valk, J.-M.; Claridge, T.D.W.; Brown, J.M. Synthesis and Chemistry of a New P-N Chelating Ligand: $(R)$ and (S)-6-(2'-Diphenylphosphino-1'-naphthyl)phenanthridine. Tetrahedron Asymmetry 1995, 6, 2597-2610. [CrossRef]

6. Pictet, A.; Ankersmit, H. Ueber Phenanthridin. J. Chem. Ber. 1889, 22, 3339-3344. [CrossRef]

7. Walton, J.C. Synthetic Strategies for 5- and 6-Membered Ring Azaheterocycles Facilitated by Iminyl Radicals. Molecules 2016, 21, 660. [CrossRef]

8. Zhang, B.; Studer, A. Recent advances in the synthesis of nitrogen heterocycles via radical cascade reactions using isonitriles as radical acceptors. Chem. Soc. Rev. 2015, 44, 3505-3521. [CrossRef]

9. Tumir, L.-M.; Stojković, M.R.; Piantanida, I. Come-back of phenanthridine and phenanthridinium derivatives in the 21st century. Beilstein J. Org. Chem. 2014, 10, 2930-2954. [CrossRef]

10. Fan, J.; Li, L.; Zhang, J.; Xie, M. Expeditious synthesis of phenanthridines through a Pd/MnO2-mediated $\mathrm{C}-\mathrm{H}$ arylation/oxidative annulation cascade from aldehydes, aryl iodides and amino acids. Chem. Commun. 2020, 56, 2775-2778. [CrossRef]

11. Yang, S.-Y.; Han, W.-Y.; Zhang, D.-L.; Zhou, X.-J.; Bai, M.; Cui, B.-D.; Wan, N.-W.; Yuan, W.-C.; Chen, Y.-Z. Synthesis of Phenanthridines through Palladium-Catalyzed Cascade Reaction of 2-Halo-N-Ms-arylamines with Benzyl Halides/Sulfonates. Eur. J. Org. Chem. 2017, 996-1003. [CrossRef] 
12. Kishi, A.; Moriyama, K.; Togo, H. Preparation of Phenanthridines from o-Cyanobiaryls via Addition of Organic Lithiums to Nitriles and Imino Radical Cyclization with Iodine. J. Org. Chem. 2018, 83, 11080-11088. [CrossRef] [PubMed]

13. Lu, S.-C.; Li, H.-S.; Gong, Y.-L.; Zhang, S.-P.; Zhang, J.-G.; Xu, S. Combination of PhI(OAc) $)_{2}$ and 2-Nitropropane as the Source of Methyl Radical in Room-Temperature Metal-Free Oxidative Decarboxylation/Cyclization: Construction of 6-Methyl Phenanthridines and 1-Methyl Isoquinolines. J. Org. Chem. 2018, 83, 15415-15425. [PubMed]

14. Chen, W.-L.; Chen, C.-Y.; Chen, Y.-F.; Hsieh, J.-C. Hydride-Induced Anionic Cyclization: An Efficient Method for the Synthesis of 6-H-Phenanthridines via a Transition-Metal-Free Process. Org. Lett. 2015, 17, 1613-1616. [CrossRef]

15. Yang, J.-C.; Zhang, J.-Y.; Zhang, J.-J.; Duan, X.-H.; Guo, L.-N. Metal-Free, Visible-Light-Promoted Decarboxylative Radical Cyclization of Vinyl Azides with N-Acyloxyphthalimides. J. Org. Chem. 2018, 83, 1598-1605. [CrossRef]

16. Pellissier, H. Enantioselective Vanadium-catalyzed Transformations. An Update. Coord. Chem. Rev. 2020. [CrossRef]

17. Langeslay, R.R.; Kaphan, D.M.; Marshall, C.L.; Stair, P.C.; Sattelberger, A.P.; Delferro, M. Catalytic Applications of Vanadium: A Mechanistic Perspective. Chem. Rev. 2019, 119, 2128-2191. [CrossRef]

18. Pellissier, H. Recent Advances in Enantioselective Vanadium-catalyzed Transformations. Coord. Chem. Rev. 2015, 284, 93-110. [CrossRef]

19. Li, Z.; Yamamoto, H. Hydroxamic Acids in Asymmetric Synthesis. Acc. Chem. Res. 2013, 46, 506-518. [CrossRef]

20. Plass, W. Chiral and Supramolecular Model Complexes for Vanadium Haloperoxidases: Host-guest Systems and Hydrogen Bonding Relays for Vanadate Species. Coord. Chem. Rev. 2011, 255, 2378-2387. [CrossRef]

21. Volcho, K.P.; Salakhutdinov, N.F. Asymmetric Oxidation of Sulfides Catalyzed by Titanium and Vanadium Complexes in the Synthesis of Biologically Active Sulfoxides. Russ. Chem. Rev. 2009, 78, 457-464. [CrossRef]

22. North, M.; Usanov, D.L.; Young, C. Lewis Acid Catalyzed Asymmetric Cyanohydrin Synthesis. Chem. Rev. 2008, 108, 5146-5226. [CrossRef] [PubMed]

23. Bolm, C. Vanadium-catalyzed Asymmetric Oxidations. Coord. Chem. Rev. 2003, 237, 245-256. [CrossRef]

24. Blanc, A.; Toste, F.D. Enantioselective Synthesis of Cyclic Ethers through a Vanadium-Catalyzed Resolution/Oxidative Cyclization. Angew. Chem. Int. Ed. 2006, 45, 2096-2099. [CrossRef]

25. Han, L.; Liu, C.; Zhang, W.; Shi, X.-X.; You, S.-L. Dearomatization of tryptophols via a vanadium-catalyzed asymmetric epoxidation and ring-opening cascade. Chem. Commun. 2014, 50, 1231-1233. [CrossRef]

26. Han, L.; Zhang, W.; Shi, X.-X.; You, S.-L. Dearomatization of Indoles via a Phenol-Directed Vanadium-Catalyzed Asymmetric Epoxidation and Ring-Opening Cascade. Adv. Synth. Catal. 2015, 357, 3064-3068. [CrossRef]

27. Sako, M.; Takeuchi, Y.; Tsujihara, T.; Kodera, J.; Kawano, T.; Takizawa, S.; Sasai, H. Efficient Enantioselective Synthesis of Oxahelicenes Using Redox/Acid Cooperative Catalysts. J. Am. Chem. Soc. 2016, 138, 11481-11484. [CrossRef]

28. Neuhaus, W.C.; Kozlowski, M.C. Diastereoselective Synthesis of Benzoxanthenones. Chem. Asian J. 2020, 15, 1039-1043. [CrossRef]

29. Takizawa, S.; Gröger, H.; Sasai, H. Vanadium in Asymmetric Synthesis: Emerging Concepts in Catalyst Design and Applications. Chem. Eur. J. 2015, 21, 8992-8997. [CrossRef]

30. Sako, M.; Aoki, T.; Zumbrägel, N.; Schober, L.; Gröger, H.; Takizawa, S.; Sasai, H. Chiral Dinuclear Vanadium Complex-mediated Oxidative Coupling of Resorcinols. J. Org. Chem. 2019, 84, 1580-1587. [CrossRef]

31. Sako, M.; Sugizaki, A.; Takizawa, S. Asymmetric Oxidative Coupling of Hydroxycarbazoles: Facile Synthesis of (+)-Bi-2-hydroxy-3-methylcarbazole. Bioorg. Med. Chem. Lett. 2018, 28, 2751-2753. [CrossRef] [PubMed]

32. Sako, M.; Ichinose, K.; Takizawa, S.; Sasai, H. Short Syntheses of 4-Deoxycarbazomycin B, Sorazolon E, and (+)-Sorazolon E2. Chem. Asian J. 2017, 12, 1305-1308. [CrossRef] [PubMed]

33. Takizawa, S.; Kodera, J.; Yoshida, Y.; Sako, M.; Breukers, S.; Enders, D.; Sasai, H. Enantioselective Oxidative-Coupling of Polycyclic Phenols. Tetrahedron 2014, 70, 1786-1793. [CrossRef]

34. Takizawa, S.; Arteaga, F.A.; Yoshida, Y.; Kodera, J.; Nagata, Y.; Sasai, H. Vanadium-Catalyzed Enantioselective Friedel-Crafts-Type Reactions. Dalton Trans. 2013, 42, 11787-11790. [CrossRef] [PubMed] 
35. Zumbrägel, N.; Sako, M.; Takizawa, S.; Sasai, H.; Gröger, H. Vanadium-Catalyzed Dehydrogenation of $N$-Heterocycles in Water. Org. Lett. 2018, 20, 4723-4727. [CrossRef] [PubMed]

36. Lu, R.; Cao, L.; Guan, H.; Liu, L. Iron-Catalyzed Aerobic Dehydrogenative Kinetic Resolution of Cyclic Secondary Amines. J. Am. Chem. Soc. 2019, 141, 6318-6324. [CrossRef]

(C) 2020 by the authors. Licensee MDPI, Basel, Switzerland. This article is an open access article distributed under the terms and conditions of the Creative Commons Attribution (CC BY) license (http://creativecommons.org/licenses/by/4.0/). 